\title{
Learning Linguistics by Doing: The Secret Virtues of a Language Constructed in the Classroom*
}

\author{
Federico Gobbo \\ University of L'Aquila
}

\begin{abstract}
The teaching of second languages in school classrooms is often conducted through the use of 'direct' and 'immersion' methods, while grammar is reserved for the first language. However, pupils spontaneously raise important questions for general and theoretical linguistics which could be better addressed through an interlinguistic comparison of first and second language grammars in the pupils' repertoires. This paper explains the method used in a pilot experiment in fieldwork. The experiment was conducted in
\end{abstract}

\footnotetext{
* The author thanks all the staff of the Montessori school in via Milazzo, Milan, Italy for the collaboration in the fieldwork, and in particular: the teachers Chiara Bonizzoli and Patrizia Pradella, and the head Costanza Buttafava, for the possibility to inspect Maria Montessori's manuscript Psicogrammatica, which we all hope that will be published soon. A special acknowledgement goes to Grazia Honegger Fresco, who offered a wonderful tea time to the author, where language teaching and many other stuffs were discussed.
}

Federico Gobbo

Dipartimento di Scienze dell'Informazione, Ingegneria e Matematica (DISIM)

University of L'Aquila, via Vetoio, IT-67100 L'Aquila, Italy

Phone: 0039-3455135665; Email: federico.gobbo@gmail.com

Received July 24, 2013; Revised August 21, 2013; Accepted September 4, 2013. 
the fourth class of a Montessori primary school, where pupils constructed from scratch a posteriori language to be used for secret communication among themselves-but not to be used with the rest of the school. During the process of the construction of this language, all aspects were discussed in the class: phonetics and writing systems, morphology and syntax, semantics and pragmatics. The main educational result was the increase in pupils' metalinguistic awareness, as well as the confidence that they gained in their own language proficiency.

Keywords: language learning, constructed language, interlinguistics

\section{Introduction}

In recent years, the interest in languages constructed for non-auxiliary purposes-such as for games, fiction, or literaturehas grown, not only among the general public, but also among some linguists, because of their potential in educational settings. For example, Gobbo $(2005,2008)$ argues that the spread of the internet gives new life to planned languages in general, and in particular to non-auxiliary ones such as Tolkien's elvish tongues or Klingon, resulting in interesting sociolinguistic phenomena. Moreover, in her linguistics course, Schreyer (2011) sets out to study the communities of practice of $\mathrm{Na}$ 'vi (Frommer 2009) and Klingon (Okrand 1992), two non-auxiliary planned languages, in order to get ideas which will help the revitalisation of endangered languages such as Tlingit (British Columbia, Canada) and Kala (Papua New Guinea). In April 2013 there was even a "Hollywood linguistics event," where the planners of Klingon, Na'vi, and Dothraki1 were by invited by Grant Goodall, the Linguistics

1 Dothraki is a language belonging to a specific culture of George Martin's saga Games of Thrones, which was fully planned by David J. Peterson, co-founder and president of the Language Creation Society. See also: $<$ http://dothraki.com/ $>$. 
Language program Director of the University of California San Diego, to discuss their creations. ${ }^{2}$

However, the educational potentialities of constructing languages for non-auxiliary purposes are still to be explored in most areas, especially in the case of youngsters, who present specific issues in language learning. In fact, language learning in primary schools (5-10 years) is often separated into two different methods: the grammar of the first language (L1, the most important language in the repertoire at any given moment, and quite often the means of education at school) is often investigated more deeply than that of second languages (L2), as the proficiency of the students is normally higher. Furthermore, in general, within a single school, the teachers of L1 and L2 are different persons with different skills, and communication and coordination in language learning as a whole cannot, therefore, be taken for granted. There is another advantage to be considered in proposing such an activity in a school: constructing a language from scratch is not part of the standard curriculum, so it is easy to propose it as a joint project between the teachers of L1 and L2, without trespassing on their specific areas of competence. Finally, as this is a collective activity performed by the class as a whole, there are no credits, ranks, ratings, and the like. Pupils can therefore enjoy the activity in a more relaxed way, compared to their standard activities, as it is something novel.

\section{The Setting of the Experiment}

In Milan, Italy, there are two Montessori private institutes with a primary school cycle, where the main educational language is Italian, while the L2 studied in the curriculum is English. However, many of the families who decide to send their children

2 Details of the event are here: <http://ling.ucsd.edu/docs/events/hollywood.html>. 
116 Learning Linguistics by Doing: The Secret Virtues of a Language

to the Montessori schools in Milan also have other family languages. In particular, the Montessori class in which the field study was conducted consists of 24 pupils between the ages of 8 and 9, 12 males, 12 females. Besides Italian and English (an L2 for everybody), Dutch, Spanish, and Serbian are spoken within families.

During the academic year 2012-2013, there were four meetings. Two meetings of two hours each were conducted in class during regular school hours, with the main teacher present: the first one occurred in October 2012, while the second one took place in April 2013. It was important that the experiment did not require extra work outside the regular hours for the pupils, so they understood that the activity was in support of the natural flow of learning, and was not an extra-curricular, structured activity, such as, for instance, the judo class or the Munari Atelier, which are part of the ordinary offerings in that school.

However, two meetings outside of the class were organised in-between, with the main teacher (who is responsible for Italian and humanities in general) and the teacher of English, in order to get feedback from the class and to discover their needs. In particular, the goal of the main teacher was simple: pupils should have fun in learning grammar by actually doing it, because they find it boring and therefore they find difficulties in learning, having lost interest. By contrast, for the teacher of English, the goal was that pupils should use English syntax to write their English sentences, rather than that of Italian-in other words, in writing sometimes "they think in Italian using English words," as the teacher once reported very pertinently.

For the researcher, the main question was the following one: Does the collective construction of a language belonging to a class increase pupils' metalinguistic awareness, so that their proficiencies in Italian and English improve? By the end of May, the teachers had carried out the evaluation of the results, in which they judged proficiency in writing in both Italian and English. 
More details about the evaluation are given below, following the presentation of the fieldwork.

It is worth noting that teachers had worked hard during the whole academic year, so that children could develop the constructed language, building the lexicon for their messages as shared knowledge without the researcher. Many linguistic questions arose naturally during work, and the researcher also helped the teachers, giving advice and suggestions via email in the meantime. Essentially the structure of the language was decided in the presence of the researcher, while the lexicon was developed by the class with the teacher, with the researcher being informed for control purposes. Informal reports by some families state that small groups of children even played at home in building other parts of the secret language to strengthen their in-group identity, and sometimes they brought their proposals to class for evaluation and acceptance by the whole group.

Every decision concerning the structure of the secret language was conducted in class with the researcher posing 'Yes-No' questions and the pupils voting by a show of hands on issues such as: 'Should our language have the neuter beside feminine and masculine or not?' One exception was the discussion about the name of the language, which will be examined at the end of the presentation of the experiment.

\section{The Montessori's Conception of Grammar}

Maria Montessori was an Italian educator who proposed a method of education for children in the early years of the 20th century (Montessori 1912). Her method is constructivist and child-centred: pupils learn by doing, following their natural tendency to learn, while teachers are like trainers. The traditional motto is Aiutami a fare da solo, that in English sounds 'Help me 
to do things by myself.' At the time of the launch of this method, modern linguistics was still not established as a science. For this reason, Montessori's nomenclature is somewhat non-standard; however, the intensive use of vivid metaphors easily overcomes this problem. Furthermore, her basic textbook Psicogrammatica (Italian for 'psychogrammar') remains unpublished but circulates among her disciples as a manuscript, while the training of new teachers is done orally by the experienced. The following account is based on interviews and seminars given by experienced Montessori teachers to people interested in the method, and the discussions that occurred before and during the experiment. A caveat is that the method presented here for constructing a language in class is not bound to that of Montessori; furthermore it is not intended as a presentation of the method as such. However, it is reasonable to start from the existing notions of grammar known by pupils in order to avoid reinventing the wheel, or even worse, causing confusion.

Maria Montessori's term 'psychogrammar' means that grammar is rooted in cognition, and she therefore compares Italian to its ancestor Latin, or its cousin Spanish, and sometimes to non-relatives such as Arabic-the metaphor of the family being central throughout the manuscript. In fact, in the Land of Languages there is always 'the noun family'-sometimes referred to as the Royal Household. The mother of the noun familysometimes referred to as the Queen-is a large black equilateral triangle, which represents nouns (proper and common, bambina in examples (1)-(4)), while her youngest prince is carried in her arms: he takes the form of a small, light blue equilateral triangle and represents the article la, in examples (1)-(3). On the other hand, she sometimes carries an older son-in another version of the story, it is a squire-in the form of a blue equilateral triangle, which is the adjective bella, in example (1). It is important to notice that the older son sometimes stands alone, without his mother (example (2)), who always carries her little prince (the 
article) with her (example (3)). Finally, when the Queen does not want to show herself directly, she sends an ambassador, who appears as a violet isosceles triangle, tall and thin, without sons (or servants); this is the personal pronoun (example (4)).

$\begin{array}{llll}\text { (1) La bambina bella } & \text { corre velocemente. } \\ \text { the little-girl pretty } & \text { runs } & \text { quickly } \\ \text { 'The pretty little girl runs quickly, } & \end{array}$

(2) La bella corre velocemente.

the pretty runs quickly

'The pretty one runs quickly.'

(3) La bambina corre velocemente.

the little-girl runs quickly

'The little girl runs quickly.'

(4) Lei corre velocemente.

she runs quickly

'She runs quickly.'

In every Land of Languages there is a big red sun which shines in the sky on the members of the Royal Household: this is the verb (corre in examples (1)-(4)). Sometimes there is an orange moon too, as its companion, which is the adverb, (velocemente in examples (1)-(4)). Nobody works alone in the Land of Languages: on the contrary, there are many helpers, who connect distant places via pink railways (conjunctions), while directions are signed with green arcs (prepositions; in another version these are green bridges which are similar to arcs in terms of shape). When people do not want to work in this Land, they shout or cry (interjections, pictured as golden exclamation marks). The great secret of the Land of Languages-concludes Maria Montessori-is the ability of its inhabitants to disguise themselves. 
Table 1. Part of Speech according to Montessori's Psychogrammar

\begin{tabular}{|c|c|c|c|c|}
\hline Families & & & & \\
\hline $\begin{array}{c}\text { Noun-family } \\
\text { (triangles) }\end{array}$ & Nouns & Articles & Adjectives & Pronouns \\
\hline Verb-family & Verbs & $a$ & $A$ & $n$ \\
(circles) & $O$ & $o$ & & \\
\hline Helpers & Prepositions & Conjunctions & Interjections & \\
(other shapes) & $p$ & $c$ & $i$ & \\
\hline
\end{tabular}

All the parts of speech presented in the story of the Land of Languages are summarised in Table 1. For simplicity, in this paper conventions are introduced so as to avoid depicting coloured triangles, circles, and other shapes graphically: the larger triangles (nouns and adjectives) are in capitals, while the smaller ones are in lower-case; the circles are represented by the letter 'o' to recall their round shape (capital and lower-case, according to their importance); finally, all the helpers are in lower-case letters. The reader is invited to remember that examples were depicted on the blackboard in the classroom with the ordinary coloured shapes.

This description shows how Montessori's psychogrammar can be well represented through a simple dependency grammar, i.e., roughly based on the concepts of dependency and valency as outlined by Tesnière (1959). Example (1) is presented in Figure 1 below. The dependency arrows spreading from the verb can be interpreted as strong rays spreading from the red sun. The researcher chose to extend the original metaphor, which is a cognitive strategy that strengthens the conceptual framework (Lakoff 1990): intransitive verbs will have only one ray (corre in examples (1)-(4) has only the subject), transitive, two (like 'to eat'), ditransitive, three (one subject, two objects, like 'to give'). Relations between members of the noun family are represented through plain arrows, while dependencies from the verb (red sun) 
to adverbs (orange moons) are shown as dotted lines, so as to indicate their weakness and optionality-within the conceptual metaphor, they represent satellites, and so are less evident. All non-mandatory dependencies from the verb are signalled by dotted arrows. In Montessori's psychogrammar there is no explicit notion that links the noun and verb families; this convention was well understood by the class. It is important to note that dependency and valency were introduced during the construction of the secret language in class, as we shall see below.

Figure 1. A Simple Dependency Grammar of Example (1)

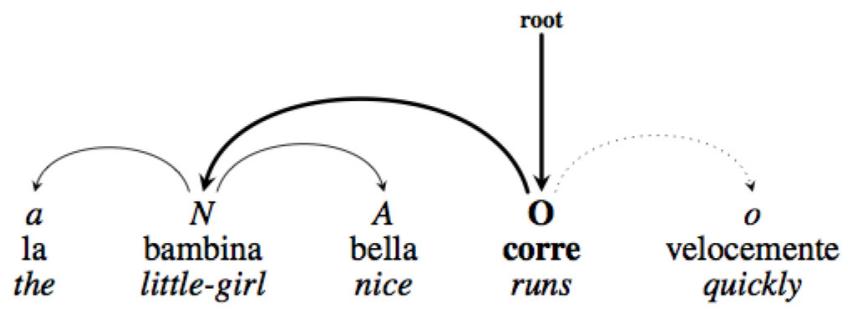

The relationships shown here demonstrate how deep is the influence of Italian on Montessori's original conception: the relationships could be slightly different in the Land of Russian, for instance, where the definite article is not morphologically marked. However, in her manuscript, Maria Montessori mentions, for example, the Spanish noun Guadalquivir (the name of a river in Andalusia, Southern Spain), which is derived from the Land of Arabic, as an example of a different arrangement of the noun family: al-wad-al-kabir means 'the great river,' hence Guad-al-quivir is literally 'river-the-great.'

If we consider the results established in language typology (Comrie 1989), Montessori's taxonomy could be questioned in terms of linguistic relativity: in particular it would hardly be valid as such for languages of the world outside the Standard Average 
European Sprachbund. On the other hand, such a discussion would be beyond the scope of this paper. For the sake of the experiment, this taxonomy is perfectly reasonable as a starting point in the settings considered, both for Italian and English. Interestingly, the language constructed by pupils partially challenged its validity, as we shall see in the next sections, proving that the method is valid not only in relation to the taxonomy of the parts of speech adopted.

\section{The Heritage of Bausani's Markuska}

Bausani (1974) describes Markuska, a secret language invented by a child-who is, in fact, himself-in order to communicate with his friends, explaining how he began to plan construction of the language. One of these friends eventually became his wife, and she confirmed in an interview with the present author ${ }^{3}$ that Markuska was used orally in some simple phrases and also in written form to compose poems. Apart from a thought experiment by Gobbo (1998), Markuska was never used as a prototype to construct languages in the classroom. Bausani notes that all a posteriori artificial languages are heavily influenced by the L1 in the nucleus of the planned language, in particular in its phonology, even if the planner is not conscious of this effect-Gobbo (2008) calls it "the Bausani effect." The experiment in the Montessori school confirms this effect, as pupils focused on the writing system of their secret language, instead of experimenting with unusual phonemes. In particular, the class agreed that "the five vowels of Italian can work perfectly," while the English vowel system "complicates everything." Even if a part of the class

3 The interview occurred in 1998 in a Bahai event in Venice, Italy, where the author could inspect a Bausani's notebook with unpublished fragments of the Markuska. 
proposed an "alien alphabet," a pragmatic argument gained most votes and so it was accepted: graphemes should be typed on a computer keyboard-using non-standard letters such as $\{\$\}$ and $\{£\}$ - so "we can send secret emails." The researcher recommended a Lautbild strategy, whereby each phoneme is written with one and only one grapheme, in order to simplify the use of the secret language, and the class enthusiastically agreed, because they did not want to bother with complex rules, such as in the Italian writing system of $\{\mathrm{ch}\}$ and $\{\mathrm{c}\}$. Accents are not fixed, and so the class agreed that they should be written explicitly on every word, unlike Italian or English, but like, for example, Portuguese.

Now the method illustrated in the creation of Bausani's Markuska could be employed. Let us start from a standard Italian sentence like il fornaio prepara il pane and we write it down in the new transcription, with a separator between morphemes: il forn-ày-o prepàr-a il pàn-e. In English, the corresponding sentence is: 'the baker prepares bread.' The researcher helped the class to note the different use of articles in the two target languages-in the Italian sentence there are two articles, in the English translation only one. Suddenly the class realised that they wanted a single invariable definite article, like English. The first move in Markuska is to write morphemes backwards, so that the former sentence would be: li nrof-yà-o ràperp-a li nàpe.

At that moment a little girl said that "the language is not so secret" because it is quite easy to spoil the mechanism. This remark is very important, because it opens the door to a more radical planning strategy to be executed in accordance with two guidelines: absolute regularity and high morphological productivity. Besides Markuska, a very well known planned language constructed following these guidelines is Volapük (for a presentation in Italian of Schleyer's original version, see Mattei 1996).

Following the little girl's remark, the researcher proposed 
124 Learning Linguistics by Doing: The Secret Virtues of a Language

changing the basic word order in order to introduce an element of exoticism, and this proposal was accepted. This strategy of partially moving the word order backwards was also adopted in Bausani's (1974) Markuska. Hence, in the new secret language, articles are postponed and attached like suffixes in terminal position: nrof-yà-o-li ràperp-a nàp-e-li. Now, the whole class decided to address the noun family first. The indefinite article is borrowed from the number ' 1 ,' and directly written as $\{1\}$ and pronounced $n u$. So, 'a baker prepares bread' is rendered as nrof-yà-o-1 ràperp-a nàp-e-li.

Pronouns were more complicated, as English has the neuter gender to mark non-animates, while Italian has masculine and feminine as the default gender for animates and non-animates. The discussion was very lively at that point, especially among a group of little girls. However, after the vote, the neuter was discarded, the masculine being unmarked, while the feminine was marked explicitly by the prefix $a \grave{\$}$-, borrowed from the backward reading of the Italian suffix -essa (e.g., professor-e versus professor-essa). On the other hand, a specific plural pronoun for the feminine gender was introduced, in order to indicate a set of feminine individuals only. This specific pronoun is à\$e-pyù, where pyù is the Italian word for 'more,' from the Latin plus. The researcher asked the pupils to translate the Italian sentence le fornaie preparano il pane, i.e., 'the bakers (women only) prepare bread,' and the answer was very interesting: à\$e-pyù nrof-yà-o-li pyù-ràperp-a nàp-e. In fact, the redundancy of the plural marker between the subject and the verb, typical in Italian, was felt to be unavoidable by the little girl who proposed the translation, where the pluraliser pyù was automatically added to the verb by analogy with the noun, but as a prefix.

At that point some of the pupils became a little worried. They asked: "Do we need to do so much work for a single sentence?" The need for regularities and hence grammar rules became evident, if too much work in constructing the language was to be 
avoided. The researcher noted the last result in detail:

(5)

$\begin{array}{lll}\begin{array}{l}\text { à\$e-pyù } \\ \text { FEM-PLUR }\end{array} & \text { nrof-yà-o-li } & \text { pyù-ràperp-a } \\ \text { nàp-e-li. } & & \text { PLUR-WORKER-o-DEF } \\ \text { bread-e-DEF } & & \\ \end{array}$

In example (5), the unclear morphemes appear in bold. Are they really useful? Can they be used to optimise the construction of the secret language?

\section{Masquerades in the Land of Languages}

Montessori's psychogrammar states that the greatest secret in the Land of Languages is the ability of its inhabitants to disguise themselves. After revising all the parts of speech (see again Table 1), the researcher and the teacher proposed ending work on the noun family, as articles and pronouns were already done. An explicit system of final suffixes to mark the main parts of speech, namely nouns $(\mathrm{N})$, adjectives $(\mathrm{A})$, verbs $(\mathrm{O})$, and adverbs (o) was proposed, borrowing the idea from Esperanto: $-o$ was assigned to nouns, $-a$ to adjectives, $-i$ to verbs, and finally $-e$ to adverbs (for a reference grammar of Esperanto, see Wennergren 2005).

A discussion arose about the suffix $-y a$, because it was felt to be "too Italian." Before the vote on the definitive derivational morpheme that signals the transformation from an object or an activity to the profession, a comparative table in Italian and English was proposed-summarized in Table 2 below. After examining many examples, children decided that the Italian -ista and the English -ist are similar, so the morpheme read backwards would be $-t s i$.

The final version of the first sentence in the secret language is 
illustrated in Figure 2 below, where the corresponding description in terms of dependency grammar is explained. The markers of the parts of speech were adapted in accordance with the new and definitive rule. And the $t s i$ was put in place. Two more changes should be underlined.

Firstly, the definite article -li on nàp-o (meaning 'bread') was deleted, as pupils decided that "bakers prepare bread in general"; here English is more logical. This remark is very interesting, because quite often language planners claim that one solution is more elegant, rational, or logical than the others in order to justify it-and the linguist should check to see if this explanation is in fact a rationalisation deriving from the L1 (Bausani effect).

Secondly, there was a remark that highlighted the advantages and limits of Montessori's taxonomy of the parts of speech, presented in Table 1. In particular, clarification through the dependency grammar of the sentence demonstrated that the strategy chosen to mark the gender and number of nouns is quite particular: there are two distinct morphs that form a small word, $a \$ \grave{e}-p y \grave{u}$, to be put before the noun. This word is neither an article (a) nor an adjective $(A)$ nor a preposition $(p)$ : in short, it does not enter Montessori's taxonomy as such. The researcher did not comment on this fact, and when a pupil asked what kind of part of speech it was ("Is it a triangle or something else?"), the question was turned over to the class. After a brief discussion, the class agreed that it should be "a kind of triangle, perhaps small [like the definite article] but in a different colour." This agreement is an interesting result, because Montessori's triangle is understood as a shape depicting the substantive dimension in general, and therefore the whole taxonomy is considered by children to be 'open,' and therefore adaptable according to needs. 
Table 2. Derivation of Professions from Activities or Objects

\begin{tabular}{|c|c|l|c|c|}
\hline Concept & Italian lexeme & Derived form & $\begin{array}{c}\text { English } \\
\text { lexeme }\end{array}$ & Derived form \\
\hline Bakery & $\begin{array}{c}\text { forn-o } \\
\text { (object: } \text { lit. oven) }\end{array}$ & forn-ai-o & $\begin{array}{c}\text { to bake } \\
\text { (activity) }\end{array}$ & $\begin{array}{c}\text { bak-er } \\
\text { (activity- } N \text { ) }\end{array}$ \\
\hline Journalism & $\begin{array}{c}\text { giornal-e } \\
\text { (object: } \text { journal) }\end{array}$ & giornal-ist-a & $\begin{array}{c}\text { journal } \\
\text { (object) }\end{array}$ & $\begin{array}{c}\text { journal-ist } \\
\text { (object- } N \text { ) }\end{array}$ \\
\hline Hairdressing & $\begin{array}{c}\text { parrucc-a } \\
\text { (object: } \text { lit. } \text { wig) }\end{array}$ & parrucch-ier-a & $\begin{array}{c}\text { hair } \\
\text { (object })\end{array}$ & $\begin{array}{c}\text { hair-dress-er } \\
\text { (object-activity- } N \text { ) }\end{array}$ \\
\hline
\end{tabular}

Figure 2. The Final Version of 'the Bakers (women) Prepare Bread'

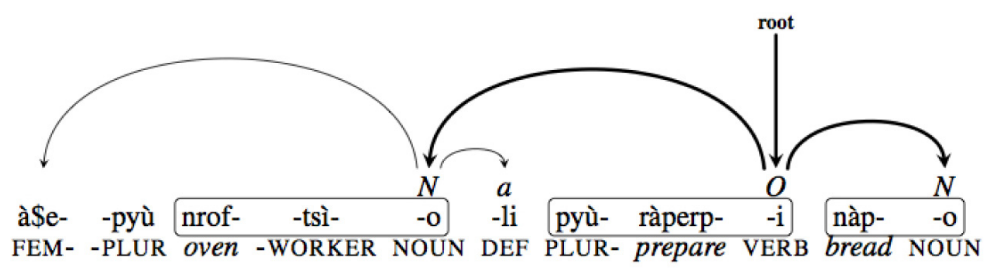

The comparison between Italian and English raised a question: "Why in English is one not allowed to say 'hair-er' or 'hair-ist' as in the Italian way?" The researcher explained that there are two different reasons: *hairer is not allowed because hair is a noun and not an activity, as the suffix -er is normally attached to verbs - "normally," because words like foreign-er (from the adjective foreign) and philosoph-er (from the noun philosophy) do exist. The reason for the impossibility of hairist is different, and it is rooted in use, not in the system-in fact 'hairist' is attested in substandard varieties of English, with a completely different meaning, i.e., somebody who discriminates against people according to the colour of their hair. Another interesting question arose afterwards: "How can we render the difference between the 
Italian giornal-ista [journalist] and giornal-aio [newspaper-seller] if we have only one modifier?" The class started to discuss this, and the accepted proposal was to start from the kiosk, i.e., the place where the newspaper-seller works. In the secret language, it is pronounced ksojk-tsi, 'kiosk-ist,' taking the English word "because 'kiosk' is clear and the word also exists in Dutch." This discussion showed that semantics is language-dependent: while the concept in English stresses the selling of the newspapers, in Italian the main concept is the newspaper itself. In the secret language, in order to solve this problem, a new metaphor was introduced: the newspaper-seller becomes a professional of the place where he or she works, i.e., the kiosk. It is also interesting to note the choice of the stem 'kiosk' to form ksojk-. The criteria adopted by the class in solving these kinds of problems-which are both semantic and pragmatic-were clarity and internationality: a strategy similar to the one adopted in planning many international auxiliary languages, like Volapük, Esperanto, or Interlingua-even if in practice the interpretation of what 'clear' or 'international' actually mean can vary greatly (for two taxonomies of these languages, see Blanke 1985 and Gobbo 2008).

As linguists are well aware, natural languages admit exceptions and "strange" phenomena in terms of morphological derivation. For instance, in Italian the adjective calmo ('calm') does not admit *calmamente, even if such adverbs exist in in Portuguese or French, e.g., calmement. Children easily found other examples by themselves: for instance, you can directly verbify the adjective facile ('easy') into facilitare ('make something easier') but the antonym difficile ('difficult') cannot be directly verbified into *difficilitare. In Montessori's terms, some inhabitants of the Land of Italian do not want to disguise themselves as adverbs or verbs.

This discussion produced an interesting remark from a young boy: "The formation of words behaves like maths; in English a red sun [verb] plus the modifier -er gives the profession, while in Italian it is the black triangle [noun] that satisfies this property." 
In pseudo-formulae:

(6) a. English profession rule: $\mathrm{O}+e r=\mathrm{N}$

b. Italian profession rule: $\mathrm{N}+i s t a=\mathrm{N}$

Following this remark, the researcher helped the children to build a multilingual lexicon, improving their comprehension of the morphology of Italian and English alike-a small fragment is presented in Table 3.

Table 3. The Secret Language as a Bridge to a Multilingual Dictionary

\begin{tabular}{|c|c|c|c|c|}
\hline Lexemes & Noun form $(\mathrm{N})$ & Adjective $(\mathrm{A})$ & Verb $(\mathrm{O})$ & Adverb (o) \\
\hline Italian & facil-ità & facil-e & facil-itare & facil-mente \\
\hline English & eas-e / eas-iness & eas-y & make eas-ier & eas-ily \\
\hline $\begin{array}{c}\text { Secret } \\
\text { language }\end{array}$ & liçàf-o & liçàf-a & liçàf-i & liçàf-e \\
\hline
\end{tabular}

According to the reports made afterwards by the teacher, this method turned out be very enjoyable for the class: pupils created a considerable part of the lexicon in groups, even during free time, discussing among themselves whether form exists more for elegance than function. Approximately 300 lemmas were produced, following the system presented in Table 3, quite often starting from nominal stems, like musica ('music'), bicicletta ('bicycle'), merenda ('snack').

Much less attention was devoted to the main other dimension of language: verbs. The verbal systems of Italian and English are complex and very different from each other, and therefore trying to synthesise them would be a major challenge even for an expert linguist, not to mention children in primary school! The researcher led the class to solve the problem by adopting a simple system: 
three basic tenses (present, future, past) and two aspects (perfective and progressive, modelled on English). Nuance would be handled by specific adverbs like before, and by series like day $(\mathrm{N})$, today's (A), and today (o). There was no time to delve into this part, but perhaps converbs (in the sense defined by Haspelmath \& König 2005) could be carefully introduced, if the intuition of the class were to be followed accordingly.

In order to complete the structure of the secret language, the "helpers" (i.e., prepositions, conjunctions, and interjections) should be exploited. Conjunctions are the easiest part of speech to be treated if a dependency grammar is used, because they link two clauses, each one being considered as a whole. Dependency grammars are useful, as they permit one to insert a labelled arc conjoining the roots of two different clauses, where the label is the conjunction itself. Figure 3 shows the conjunction but in the complex sentence 'the boy of the bar [barman] prepares a drink but everybody is dancing'-the arrow starts from the main clause.

Figure 3. A Conjunction Represented in Dependency Grammars

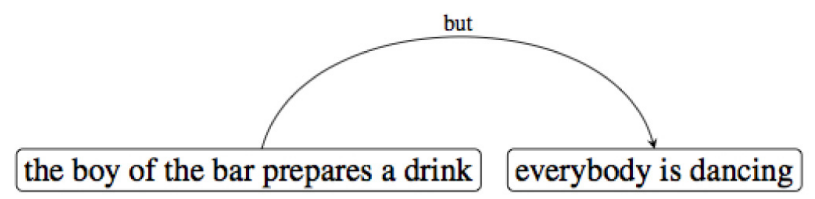

Without any doubt, interjections were the funniest part of speech for the class: children proposed many onomatopoeic forms, borrowed from comics or completely invented. However, there was no discussion here, because interjections are words or phrases used on their own, without any structure. On the other hand, prepositions were a source of non-trivial reflection. In the classroom, we recalled that in Italian as well as in English, prepositions can be attached to almost everything: articles (the Italian della is a fusion of 'of the FEM'), nouns (e.g., Italian in 
vacanza, English on holiday), pronouns (e.g., Italian a loro, English to them), adjectives (e.g., Italian in rosso, English in red), even verbs (e.g., in Italian da fare, 'to be done'). What is their function? In Montessori's terms, they help the main characters in the Land of Languages to disguise themselves. For example, quite often the preposition of disguises a noun $(N)$ as an adjective $(A)$, as in Example (7).

(7) tsàgar-o-li boy-NOUN-ART ràb-o-li-fo ràperp-i knird-o-1. drink-VERB-ART

'The boy of the bar [barman] prepares a drink.'

Although in the beginning Italian was always the first choice for the construction of the lexicon, English later became more dominant. For example, in example (7) the word for 'boy' is borrowed from the Italian stem ragazz- (from the Arabic raqquāss), while 'drink' is borrowed directly from English, following the method of reading backwards, already presented above. Interestingly, in the secret language, prepositions actually become postpositions, which are not unknown in English (e.g., the series with -ward: forward, backward, onward, and so on) but are fairly uncommon; in particular, before this experiment, pupils were not aware of their existence. The important fact is that children became aware that pre-positions or post-positions alike can help to disguise nouns as quasi-adjectives (A, see example (7)), but also help to disguise nouns $(\mathrm{N})$ as quasi-adverbs (o), like the group in summer, analysed in example (8).

(8) limàf-o-li

tsnàkav-i-fut remmùs-o-ni. family-NOUN-ART holiday-VERB-FUT summer-NOUN-in 'The family will go on holiday in summer.' 
A remarkable strategy shown in example (8) is represented by the verb, which was obtained through the direct verbification of the nominal stem tsnàkav (backwards version of Italian vacanza and English vacation), a strategy sometimes allowed in Italian (e.g., musicare 'to put a text into music') or English (e.g., sound can be a verb, a noun, or an adjective), but not in this semantic area. This solution was a concrete application of the structure imposed on the multilingual dictionary exemplified in Table 3.

When the class had finished all the parts of speech, a little boy realised that we had not yet given a name to the secret language. Unlike all previous discussions, it was difficult at this point to keep order in the classroom. In fact, many pupils proposed different names, and most reactions were very passionate: the name should refer to the class, not the school, it should not be stolen by pupils of other classes, and it acted as a mark of identity among the members if used as a greeting. This discussion was not expected by the researcher, who, in planning the experiment, had not thought about a specific moment for this important topic, nor the pragmatic use of the name as a greeting. However, the discussion took some time and it was not easy to get agreement among the different groups in the class, because the name of the secret language raised the issue of identity, which is unavoidable in any language, natural or constructed. The relationship between language and identity defines who is 'in' and who is 'out,' and in particular to whom the language belongs and therefore who is allowed to learn it. In other words, aspects of sociolinguistic use were also considered by the young language creators. The final name of the language is Araik, but the author has promised not to explain its origin, precisely because of its symbolic value. 


\section{An Evaluation of the Secret Language}

The secret language Araik was constructed a posteriori, i.e., modelled after interlinguistic comparison of the pupils' knowledge of languages, and not based on a priori ontological commitments. This choice proved to be effective, as the linguistic creativity of the pupils was stimulated, so that they understood their own linguistic capacities more deeply. The results of the fieldwork should be considered as preliminary: in fact, there was no control group, nor a careful analysis of the linguistic data. Moreover, tricky parts of grammars, such as correlatives, marked orders, and so on were outside the scope of the secret language, which is mainly meant as a written code-no problems of pronunciation in the case of sound clashes were addressed. In any case, even if an extensive data-driven study were to be carried out in a more structured setting, in order to confirm the effectiveness of the method presented here, the account given by the teachers during the period of the experiments and especially the final tests in May show preliminary but promising signs: children start to play with grammars drawing parallels and creating inductive rules from examples, without the guidance of adults.

\section{Conclusions}

In this paper, a method of constructing a language in the classroom was presented. While for children the secret language is just for fun, this is a serious game, as they seem to improve their metalinguistic awareness and the ability to actually play with linguistic structures. This experiment shows that the realm of planned languages, both for auxiliary purposes (such as Volapük or Esperanto) and for less pretentious ones (such as Klingon, $\mathrm{Na}$ 'vi, or Dothraki) is not necessarily an intellectual game with no 
134 Learning Linguistics by Doing: The Secret Virtues of a Language

practical utility. On the contrary, planned languages can be used to teach important notions of general linguistics without requiring theorisation, but rather in an active way, when learners actually create their own language.

\section{References}

Bausani, A. 1974. Le lingue inventate: linguaggi artificiali, linguaggi segreti, linguaggi universali. Rome: Astrolabio Ubaldini.

Blanke, D. 1985. Internationale Plansprachen. Berlin: Akademie Verlag.

Comrie, B. 1989. Language Universals and Linguistic Typology. Chicago, IL: University of Chicago.

Frommer, P. 2009. Some Highlights of Na'vi. Language Log 19. Available at URL <http://languagelog.ldc.upenn.edu/nll/?p=1977>. Gobbo, F. 1998. Verbigerazione fantastica. Italiano \& Oltre 3.4, 151-154.

- 2005. The Digital Way to Spread Conlangs. In S. Posteguillo et al. (eds.), Language at Work: Language Learning, Discourse, and Translation Studies in Internet 45-53. Castellon: Publicacions de la Universitat Jaume I. . 2008. Planning Languages and Language Planning: The Contribution of Interlinguistics to Cross-Cultural Communication. In F. Boers et al. (eds.), Multilingualism \& Applied Comparative Linguistics I 24-60. Newcastle upon Tyne: Cambridge Scholars Publishing.

Haspelmath, M. \& E. König. (eds.) 1995. Converbs in Cross-Linguistic Perspective. Berlin: Mouton de Gruyter.

Lakoff, G. 1990. Women, Fire, and Dangerous Things. Chicago,

IL: University of Chigaco Press.

Mattei, C. (1889) 1996. Volapük. Nozioni compendiose. Fara 
Editore. Reprint. Available at URL < http://www.liberliber.it>. Montessori, M. 1912. The Montessori Method. New York: Frederick A. Stokes Company.

Okrand, M. 1992. The Klingon Dictionary. Addendum Edition. New York: Pocket Books.

Schreyer, C. 2011. Media, Information Technology, and Language Planning: What Can Endangered Language Communities Learn from Created Language Communities? Current Issues in Language Planning 12.3, 403-425.

Tesnière, L. 1959. Eléments de syntaxe structurale. Paris: Kliencksiek.

Wennergren, B. 2005. Plena manlibro de Esperanta gramatiko. El Cerrito: ELNA. Available at URL $<$ http://bertilow.com/pmeg/>. 